\title{
IDENTIFICATION OF RISK FACTORS OF DEVELOPMENT AND OPERATION OF ROADS IN THE LIGHT OF SURVEYING WORK
}

\author{
D. SKORUPKA ${ }^{1}$, M. KOWACKA ${ }^{2}$
}

\begin{abstract}
This article aims to identify potential risk factors affecting the implementation and synchronisation of surveying and construction works during building and operation of roads. The task was executed on the basis of literature studies and experience. The article is an introduction to the research that has been conducted by the authors on the reasonably precise index of factors which one may deal with during the implementation of facilities of this type. The raised issue is crucial for financial and time reasons, but what is important in the roads construction - also for social ones, as prolonged traffic disruption adversely affects the environment.
\end{abstract}

Keywords: risk, roads, geodetic surveying, construction sector.

\section{INTRODUCTION}

In the literature [4] and in practice, the implementation of road undertakings is classified among strategic projects and treated as a great economic, technical and organizational challenge. Among the number of operations accompanying the process of roads construction, in this paper surveying work is elaborated. It is essential to the correct implementation of any facility constructing not only at the stage of preparation but also execution, control or demolition ones.

The article explores the problem of identifying risk factors of the implementation and operation of roads with a particular focus on surveying work. The identification and elimination of possible

\footnotetext{
${ }^{1}$ PhD., Eng., the Military Academy of Land Forces, Faculty of Management, ul. Czajkowskiego 109, 51-150 Wroclaw, Poland, e-mail: d.skorupka@wso.wroc.pl

${ }^{2}$ M.A., Eng., the Military Academy of Land Forces, Faculty of Management, ul. Czajkowskiego 109, 51-150 Wroclaw, Poland, e-mail: m.kowacka@wso.wroc.pl
} 
risk factors and the proper correlation of construction and geodetic works have an impact on reducing the possibility of delays and resulting from them additional costs of the objects implementation.

\section{GEODETIC WORKS DURING THE ROAD CONSTRUCTION}

Geodetic works performed at the stage of the implementation and operation of road infrastructure are made in accordance with the legal provisions, among others, geodetic and cartographic law, construction law or regulations of the Minister of Spatial Planning and Construction. Prior to the construction of roads, studies consisting of analysing and updating available maps are performed. According to [9] and [1], below there are described individual tasks within the framework of the completion of a road facility. In the initial phase a preliminary project analysis is carried out, during which the route geometry, elevation assumptions or the completeness of project documentation are checked. Next, the foredesign of a horizontal and vertical geodetic control network is elaborated. This stage involves locating horizontal and vertical control network points and suplementing them with additional points which are used both during accomplishment works as well as reconstruction and restoration ones. For this purpose, it should be borne in mind that it is significant to put bench marks in places where they are not exposed to damage. An important element is the inventory of the area for the future investment. To this end, there is made the situational and elevation measurement and a base map with complete back-up of data is created. Further, a road project is developed, which is the basis for marking a road in the terrain. At this point, sketches of staking are prepared and data, such as main points, axis runs, demarcation lines, building lines, the location of buildings and the designed terrain layout is processed.

The subsequent step is to verify the project assumptions, collect data for earthworks and develop a documentation sketch. Moving onto the issue of demolition works, their inventories have to be performed, that is measurements and the documentation necessary for continuing work at further stages. The existing road infrastructure and engineering facilities may be demolished. In addition to the work mentioned above, before the implementation of a road facility or at the dismantling, there must be made an inventory of completed works associated with shaping the road body. These are field situational and elevation measurements, the purpose of which is to verify the work performed with regard to project specifications and, if the compliance is achieved, prepare the acceptance documentation. 
During construction works the bottom of the trench, soil stabilisation with cement, the substructure made of natural and aggregate crushed-stone, the bitumen foundation, the asphalt binder course and the asphalt wearing course are subject to measurements.

\section{THE SPECIFICATION OF RISK FACTORS}

On the basis of the literature [2] and [3] on the risk analysis, the above outlined activities performed at the implementation of roads and the authors' own observations, below there are presented examplary risk factors divided into two types: risk factors arising from construction works and those ones arising from surveying works.
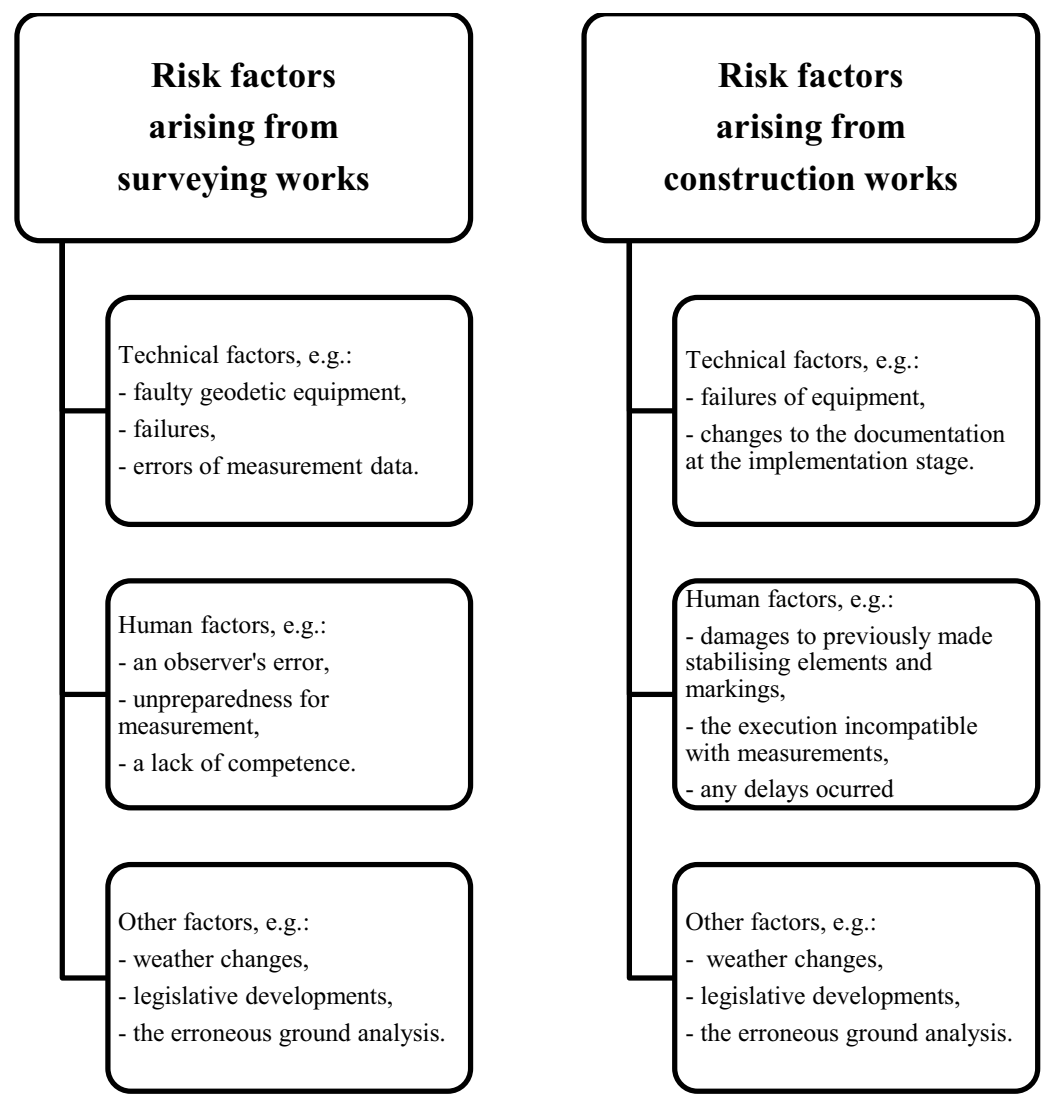

Fig. 1. The division of risk factors Source: own elaboration 
The major reason for such a division is the mutual influence of these processes on each other, as any delay in construction work delays the latter. It should be remembered that the surveying companies declaring their participation in a construction project are simultaneously involved in other ones and any schedule changes have a significant impact on further delays that finally are connected with finances and the loss of potential new customers. Moreover, risk factors are broken down into technical, human and environmental ones. Also external factors can be extracted, such as social unrests and traffic disruptions, but they fall within the scope of interest of a separate paper. This is not a final proposal of the risk factors classification that can be done for any such work being performed because each undertaking has its specific framework, the inclusion of which in particular may affect the occurrence of potential risk factors. The proposal presented in Figure 1 constitutes a starting point for the further analysis, that is, precisely, the identification, quantification, reduction and final risk assessment.

\section{THE IDEOGRAPHIC MODEL OF THE IDENTIFICATION OF RISK FACTORS}

Different methods can be used to identify risks in a project. Among them there are two very popular in practice: Experience - Based Risk Assessment and Brainstorming - Risk-Based Assessment. They are simple, but vague.

In the work the authors propose the risk identification method based on the scheme of idea used in the method MOCRA (Method of Construction Risk Assessment) [7, 8]. The main difference is that risk factors are divided into: factors resulting from construction work and factors arising from surveying work. The schematic diagram of the identification of risk factors is presented in Fig. 2. It presents essential elements which are used for the specification of risk factors existing in the construction project in question. 


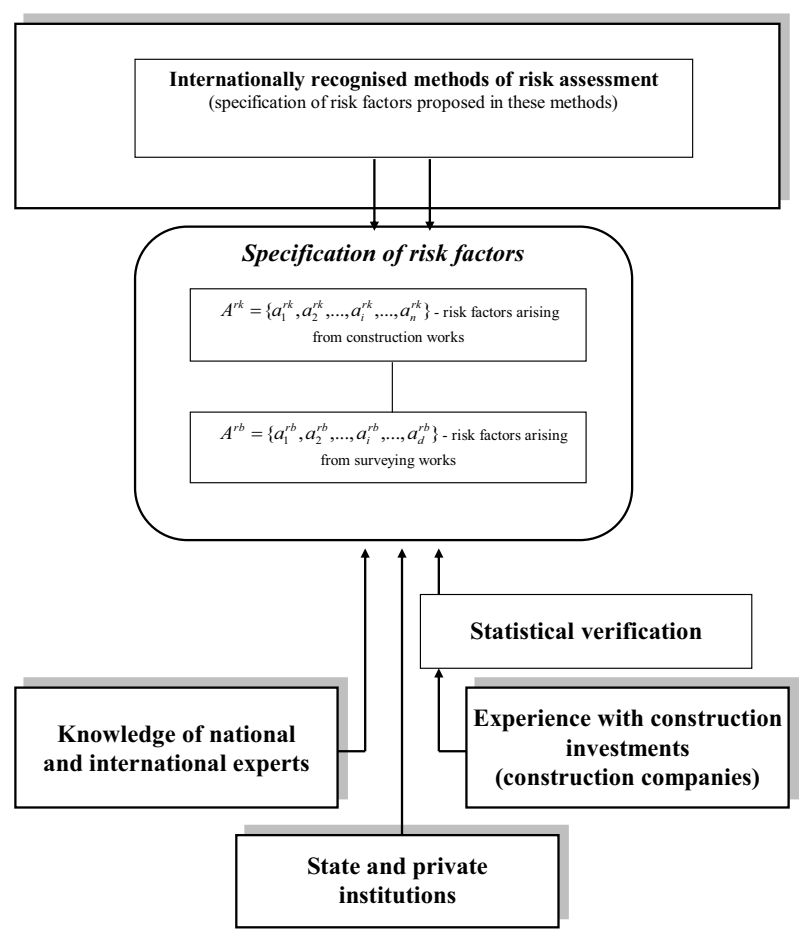

Fig. 2. The ideographic model of the identification of risk factors Source: own elaboration

The risk analysis must not come to an end with the identification of risk factors. In the further process they should be quantified and reduced (these problems are being in the course of solving). The proper and reliable identification is, however, the foundation of an effective method of the risk analysis, this is why it was chosen as a main point of this paper.

\section{SUMMARY}

Risk management procedures are increasingly used in practice and sometimes even they are imposed in a formal way. This fact results from raising the level of awareness among policy makers, investors and engineers realising various projects, including construction undertakings. Taking into account the experience, the direction and pace of development this type of analysis seems reasonable. 
In this paper the authors focused on the example of a building project for the road construction. The choice of this type of a project was not accidental. It resulted from the awareness of frequent disruptions in the implementation of such facilities, which negatively affect the cost and time of the execution of road investments.

The analysis proposed in the work is an introduction to a broader method that is being developed by the team of the authors.

\section{REFERENCES}

1. A. Jagielski, Geodezja II, Wydawnictwo P.W. Stabill, Kraków, 2003.

2. A. Leśniak, E. Plebankiewicz: Opóźnienia $w$ robotach budowlanych, Zeszyty Naukowe Wyższej Szkoły Oficerskiej Wojsk Lądowych, 3 (157), Wrocław, s. 332-339, 2010.

3. A. Leśniak, Skąd się biorą opóźnienia?, [w:] „Builder”, nr 1, s. 24-25, 2010.

4. A. Sobotka, D. Pawluś, D. Wałach, A. Czarnigowska, Badanie procesów logistycznych przedsięwzięć drogowych, Budownictwo i inżynieria środowiska, Rzeszów, s. 113-120, 2012.

5. B. Wiatr, Prowadzenie geodezyjnej obsługi budownictwa drogowego, kolejowego i wodnego, Poradnik dla ucznia, Radom, 2007.

6. D. Skorupka, A. Duchaczek, Kwantyfikacja ryzyka w zarządzaniu przedsięwzięciem budowlanym, Ludzie, zarządzanie, gospodarka, Rok 17, Nr 1, 2013.

7. D. Skorupka, D. Kuchta, Metody oceny ryzyka w przedsięwzięciach budowlanych, WSOWL, Wrocław, 2013.

8. D. Skorupka, D. Kuchta, M. Górski, Zarządzanie ryzykiem w projekcie, WSOWL, Wrocław, 2012.

9. Instrukcja Techniczna G-3 „Geodezyjna obsługa inwestycji”.

10. M. Połoński, K. Pruszyński, Ryzyko projektowania przedsięwzięć inżynierskich, Wiadomości Projektanta Budownictwa, nr 1, s. 23-27, 2008

11. M. Rogalska, A. Czarnigowska, Z. Hejducki, T. O. Nahurny, Metody wyznaczania czasu trwania procesów budowlanych z uwzględnieniem pogodowych czynników ryzyka, Przegląd budowlany, nr 1, s. 37-42, 2006.

12. O. Kapliński i inni, Metody i modele badań w inżynierii przedsięwzięć budowlanych, Wydawnictwo PAN KILiW IPPT, Warszawa, 2007.

13. T. Kasprowicz, Inżynieria przedsięwzięć budowlanych, Wydział Inżynierii, Chemii i Fizyki Technicznej Wojskowej Akademii Technicznej, Warszawa, 2002.

\section{LIST OF FIGURES AND TABLES:}

Fig. 1. The division of risk factors

Fig. 2. The ideographic model of the identification of risk factors

Rys. 1. Podział czynników ryzyka

Rys. 2. Model ideograficzny identyfikacji czynników ryzyka 


\section{IDENTYFIKACJA CZYNNIKÓW RYZYKA REALIZACJI I EKSPLOATACJI DRÓG W ŚWIETLE PRAC}

\section{GEODEZYJNYCH}

Keywords: ryzyko, drogi, geodezja, budownictwo.

\section{STRESZCZENIE:}

Praca miała na celu zidentyfikowanie potencjalnych czynników ryzyka towarzyszącym realizacji oraz synchronizacji prac geodezyjnych i budowlanych podczas budowy i eksploatacji dróg. Temat zrealizowano na podstawie studium literatury oraz doświadczenia. Jest to wstęp do prowadzonych przez zespół autorski badań nad możliwie precyzyjnym indeksem czynników z jakimi można mieć do czynienia podczas realizacji tego typu obiektów. Poruszony problem jest istotny ze względów finansowych, czasowych, ale co ważne przy budowie dróg, również społecznym, gdyż przedłużające się utrudnienia w ruchu wpływają niekorzystnie na otoczenie. Przystępując do tematu wyszczególniono prace geodezyjne realizowane podczas budowy dróg, takie jak np. wstępna analiza projektu, założenie geodezyjnej osnowy poziomej i pionowej czy opracowanie projektu drogowego.
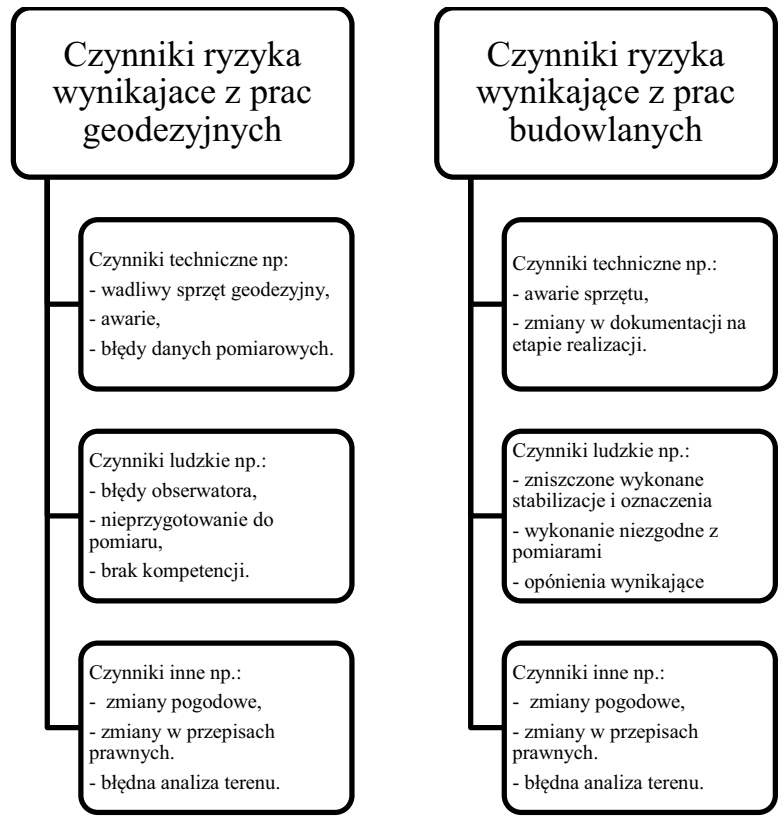

Rys. 1. Podział czynników ryzyka Źródło: opracowanie własne

Prace geodezyjne są wykonywane nie tylko podczas realizacji budowy dróg, ale również podczas ich rozbiórki lub przebudowy. Ich scharakteryzowanie dało początek dalszym analizą, które doprowadziły do sporządzenia podziału czynników ryzyka. Czynniki ryzyka podzielono na te, które wynikają z prac geodezyjnych oraz te wynikające z prac 
budowlanych. Obie te grupy wzajemnie się przenikają i mają bezpośredni wpływ, ponieważ zmiana terminu realizacji prac budowlanych powoduje zmianę daty rozpoczęcia prac geodezyjnych i odwrotnie. Zaproponowany przez autorów podział czynników ryzyka przedstawiony na rysunku 1 dalej dzieli się na czynniki techniczne, ludzkie oraz inne, gdzie można zakwalifikować zmiany pogodowe lub prawne. Punktem kluczowym do sporządzenia tej pracy było przedstawienie modelu ideograficznego identyfikacji czynników ryzyka (rysunek 2). Przedstawiono na nim zasadnicze elementy, które wykorzystywane są do specyfikacji czynników ryzyka występujących w danym przedsięwzięciu budowlanym.

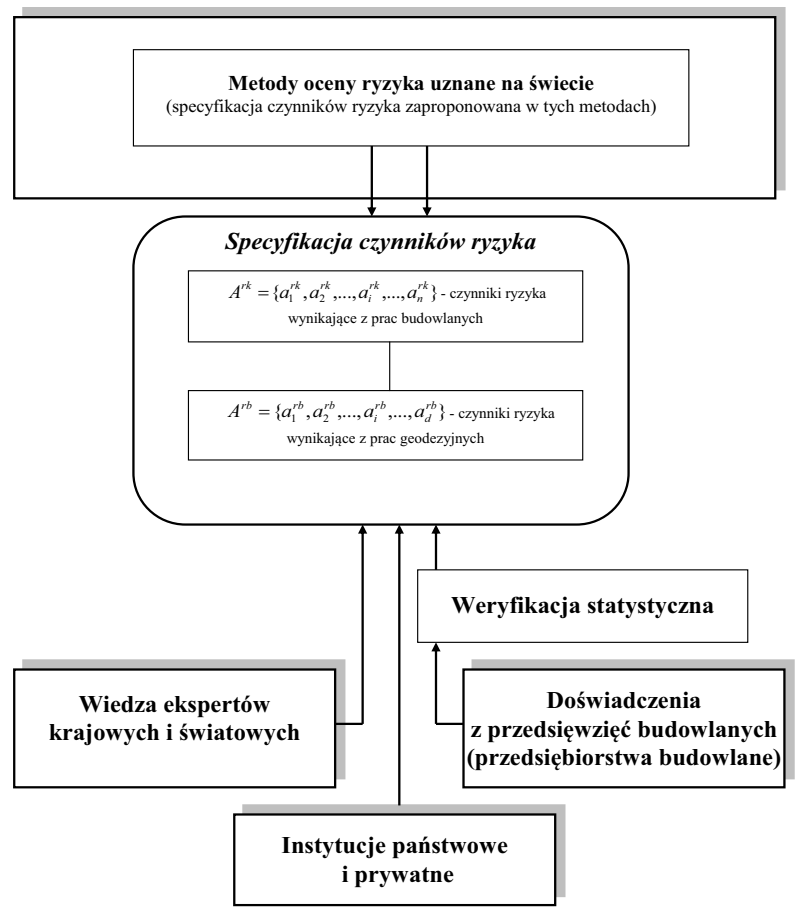

Rys. 2. Model ideograficzny identyfikacji czynników ryzyka Źródło: opracowanie własne

Identyfikacja czynników ryzyka to dopiero wstęp do poprawnej analizy ryzyka, ale od tego jak ją przeprowadzimy zależy efekt końcowy prac, które aktualnie realizowane są przez autorów. Poprawna współpraca pomiędzy realizatorami prac geodezyjnych i budowlanych jest bardzo ważna i przynosi obopólne korzyści. Czasochłonność, poniesione koszty jak również zasadność tych prac w procesie realizacji dróg w istotny sposób zwiększają wagę prowadzonych badań. Efekty końcowe prac mogą mieć kluczowe znaczenie w poprawie realizowanych przedsięwzięć. 